\title{
Using the SCAMPER Model to DevelopTranslation Skills for Major Students in the Faculty of Education, Majmaah University, Saudi Arabia
}

\author{
Fatma Farid Fakhry Tharwa \\ Department of Curriculum and Teaching Methods \\ Faculty of Education, the New Valley University, Egypt \\ $\&$ \\ Faculty of Education, Majmaah University, Riyadh, Saudi Arabia
}

\begin{abstract}
This paper aims at identifying the effectiveness of using the SCAMPER model in developing translation and raising the attitudes towards adaptation among major students in the faculty of education, Majmaah University, Saudi Arabia. It tries to answer the following questions: To what extent would using the SCAMPER model raise translation skills among major students in the faculty of education - Majmaah University the the second question is To what extent would using SCAMPER model raise the attitudes towards translation among major students. To accomplish the purpose of the study, the researcher showed the experimental group with a sample involved (40) students for the SCAMPER Model in the first term of the school year 2018-2019. The researcher used (pre -post \& delayed) translation test, a scale of students' attitudes towards translation to collect data. The study's results suggested that there were statistically important differences at $(\alpha \leq 0.05)$ in the whole mean grade in the pre post translation test to the group in favor of posttest. Also, there were statistically important differences at $(\alpha \leq 0.05)$ in the whole mean grade in the pre-post scale of students attitudes towards translation to the group in favor of post implication. Also, the researcher recognized these differences in using the SCAMPER Model in teaching English language translation. In light of these outcomes, the study suggested the necessity of applying the SCAMPER Model in teaching the English language to get better results in students' translation learning and retention in English as a foreign language. Similarly, the SCAMPER Model would be used with other English skills and sub-skills.
\end{abstract}

Keywords: Model, SCAMPER, skills, translation

Cites as: Tharwa, F. F.F. (2019). Using the SCAMPER Model to Develop Translation Skills for Major Students in the Faculty of Education, Majmaah University, Saudi Arabia. Arab World English Journal for Translation \& Literary Studies, 3 (2).91-113

DOI: http://dx.doi.org/10.24093/awejtls/vol3no2.9 